\title{
Lidil
}

Revue de linguistique et de didactique des langues

$41 \mid 2010$

Énonciation et rhétorique dans l'écrit scientifique

\section{Head nouns as modal stance markers -academic texts vs. legal texts}

Issa Kanté

\section{CpenEdition}

Journals

Édition électronique

URL : http://journals.openedition.org/lidil/3022

DOI : 10.4000/lidil.3022

ISSN : $1960-6052$

Éditeur

UGA Éditions/Université Grenoble Alpes

Édition imprimée

Date de publication : 30 mai 2010

Pagination : 121-135

ISBN : 978-2-84310-167-0

ISSN : 1146-6480

\section{Référence électronique}

Issa Kanté, "Head nouns as modal stance markers -academic texts vs. legal texts », Lidil [En ligne], 41 | 2010, mis en ligne le 30 novembre 2011, consulté le 19 avril 2019. URL : http://

journals.openedition.org/lidil/3022 ; DOI : 10.4000/lidil.3022

(c) Lidil 


\title{
Head nouns as modal stance markers -academic texts vs. legal texts
}

\author{
Issa Kanté*
}

\begin{abstract}
The aim of this paper is to substantiate on the one hand that head nouns are modal expressions allowing the writer to mark her stance in the text. On the other hand, it shows that the purpose and the social role of a text can be perceived in both its lexical expressions and grammatical patterns. Thus, this paper, which is a corpus-based study, shows that the use and the frequency of head nouns are distributed along text genres. The paper also agues that head nouns and that-clauses in which they appear may not have the same communicative functions and effects according to text genres, which is to say that the same head noun or that-clause may not have the same discursive functions or effects in two genres of text. The contrast between legal and academic corpora has enabled us to substantiate these claims.
\end{abstract}

\section{RÉSUMÉ}

Cet article a pour objectif de montrer d'une part que les noms recteurs sont des expressions modales qui marquent la présence de l'auteur dans le texte. D'autre part, il montre que le but discursif et le rôle social d'un texte est perceptible dans ses structures lexicales et grammaticales. Axée sur le discours académique et juridique, l'étude révèle en effet que l'emploi et la fréquence des noms recteurs peuvent être corrélés aux genres de discours. Elle montre également qu'un même nom recteur ou un même type de complétive en that employé dans deux genres de textes n'aurait pas les mêmes fonctions ou effets discursifs.

* CRIDAF (EA 453), Université Paris 13, Villetaneuse, France. 


\section{Aims of the study}

This paper ${ }^{1}$ is a corpus-based study investigating the presence writers or speakers in their discourse through certain types of head nouns, such as fact, statement, assumption, etc. These nouns, contrary to many others, have the particularity to govern complement that-clauses, such as in:

In this way, if the highest ranked speakers can be correlated across verbal paradigms, the assumption that rank order scales can be correlated across environments is validated. $\left(\mathrm{JEL}^{2}\right)$

Previous linguistic works, using different approaches, have categorized these nouns (called "head nouns", complement "that-taking nouns", or "shell nouns") in lexical classes and subclasses (Nomura, 1993; Schmid, 2000; Aktas \& Cortes, 2008). Some authors like Quirk et al. (1985, p. 1231, pp. 1260-1) and Huddleston et al. (2002, p. 965) claim that the ability of these nouns to govern a that-clause is justified by either their abstractness, or by their semantic relation to verbs or adjectives from which they are. These accounts might not be fully satisfactory since neither all the head nouns are abstract (sign, picture, etc.), nor all of them are derived from verbs or adjectives (fact, idea, etc.) Ballier (2004a).

Other typological approaches, Perkins (1983, pp. 86-8) and Chevalier \& Léard (1996) for instance, have shown that modality is one of the main semantic features of such nouns. Put another way, nouns that govern complement that-clauses are nominalized expressions of modality; viz. they are used by the speaker to convey a modal characterization. Based on this analysis, we contrast a legal and an academic text to show how these kinds of nominal expressions are used by the writer or speaker to mark her own stance. Another aim of this study is to figure out if the functions of a head noun or a particular that-clause change according to text genres. In other words: Do the communicative functions of a head noun and the pattern in which it appears vary from a genre of text to another?

1. Special thanks to Nicolas Ballier, Raphael Salkie and Natalia Ciolko for their advice and perceptive comments on earlier versions of this paper. Any remaining flaws are mine alone.

2. Journal of English Linguistics (academic corpus). 


\section{Corpora}

\section{The linguistic corpus}

It is composed of 16 research papers published from 2000 to 2007, written by both non-native and native speakers of English. All of the papers (including three book reviews and one interview) were retrieved from the website ${ }^{3}$ of the Journal of English Linguistics. The corpus contains around 100,000 words.

\section{The legal corpus}

Our legal corpus is an extract from an online corpus, Old Bailey Proceedings from 1674 to 1834, which contains 25 million words ${ }^{4}$, and Proceedings of the Central Criminal Court (70 million words of text), extending the period covered to $1913^{5}$. The corpus is made up of transcribed and marked up texts of felony trial reports published in the Old Bailey Proceedings from 1674 to 1913 . That is to say that our legal corpus is the transcription of courtroom interactions and reports. Thus, compared to the linguistic corpus, which is an academic genre, the legal one is rather a professional genre.

In order to have two corpora of equal size, we retrieved from the last part of the Old Bailey Proceedings corpus (January and February 1913) an equivalent of 100,000 words. Notice that we are aware of the diachronic and stylistic differences between our two corpora. For instance, the dimension of reported speech is much more important in the legal text than in the linguistic one.

\section{A contrastive standpoint}

Our interest to compare an academic text with a legal text is motivated by two main reasons. The first is to show if the source of modality and its extra-linguistic goals are determinant in text specificity. Head nouns that complement that-clauses are not used only for the lexical semantic meaning they convey, but also for a calculated and particular modal meaning. So, the clear-cut distinction between the legal genre (interactions in courtroom) and the academic genre (a somewhat

3. <http://eng.sagepub.com/>.

4. <http://ahds.ac.uk/ictguides/projects/project.jsp?projectId=156>.

5. <http://www.shef.ac.uk/hri/projects/projectpages/centralcriminalcourt.html>. 
one-way discourse, in the case of research papers) is a sound ground for substantiating discursive and contextual differences in terms of modal characterizations and their implications in the real world. The differences (linguistic to extra-linguistic dimensions) between a legal and an academic text may be displayed in the choice and frequency of head nouns.

The second reason is to understand if text genre differences are neutralized when the speaker uses nominal that-clauses in her discourse. The questions are: Does the speaker in the academic genre and in the courtroom one use that-clauses for the same communicative functions and effects? Do the differences in terms of social role between texts necessarily mean differences in communicative functions and effects? The analysis of corpora from two highly distinctive genres seems to be a good strategy to answer such questions.

\section{Hypotheses}

Our working hypotheses are the following:

- head nouns are modal expressions used by the speaker/writer to mark her stance towards a proposition (Ballier, 2004b), an event or a state;

- the use of a head noun in a given grammatical pattern in two genres of text may not have the same purpose or implication. For example, the epistemic noun evidence in a given complement that-clause may not have either the same purpose or the same implication in a legal and in an academic text;

- the social role of a discursive genre may also be displayed in the lexical expressions of its texts. For instance, the authoritative role of the legal institution may be noticed in the use of certain deontic nominal expressions and their immediate syntagmatic environment. Similarly, the persuasive and argumentative aim of linguistic papers may be exhibited in the frequency of certain epistemic expressions. 


\section{Data analysis}

\section{Lexico-grammatical patterns and their functions}

The lexico-grammatical patterns in which we are interested here are the following: $[\mathrm{N}$ that $]$, [Presentative $\mathrm{N}$ that $]$, $[\mathrm{N}$ be that $]$. In addition to these three patterns there are other cases where the head noun collocates with either a verb to govern a that-clause (Figure 3 makes the point that in the sixteenth century, the process away from multiple negation was particularly favored by men ... JEL), or with a preposition (in the sense/on the basis that ...).

\section{I.1. Simple N complement clause [N that-clause]}

(1) EDITH ANN WAGHORN He [MAX ALEXANDER] wrote on February 25, "I have received quite a fortune; in fact over $£ 3,000$ in subscriptions, for which I pay 100 per cent. per annum [...] MAX ALEXANDER (prisoner, on oath) [...] The statement that I was paying 100 per cent. on $£ 300$ is a lie in the legal sense." $\left(\mathrm{OBP}^{6}\right)$

(2) Ariel's general assumption that demonstratives are intermediate or mid-accessibility markers is still broadly supported because the cases in this corpus are relatively short-range anaphors. (JEL)

This construction can be considered the prototype of complement that-clauses since the head noun alone governs the subordinate clause. The semantic function of this construction is to express the speaker's stance towards a proposition, an event, or a state which has already been expressed mentally or verbally. In other words, this complement clause is a sort of indirect modal expression on an already expressed proposition, a previously noticed event or state. In (1) for example, the speaker (Max Alexander) asserts that what another person (Edith Ann Waghorn) said is not true. Through the head noun, the speaker 'wraps' the propositional content in a characterizing noun (statement), and then expresses a personal judgment (... is a lie ...) about it. Thus the subordinate clause, characterized by the head noun, is in fact a kind of reported speech. In example (1), we can clearly see that the that-clause refers back to, or even reports a speech that has been expressed earlier in the text. The speaker does not limit himself to just a report, but characterize

6. Old Bailey Proceedings (legal corpus). 
the proposition and gives his personal opinion about its content. Hence Biber et al.'s (1999, p. 648) claim that "the that-clause reports a proposition, while the head noun reports the author's stance towards that proposition." The same mechanism happens in (2); the writer creates a modal characterization and marks her personal stance about an already expressed position. The characterization Ariel's general assumption shows that the writer refers to a preconstruction, not necessarily in her own text, but in someone else's analyses (Ariel's).

Thus, in terms of text specificity, the semantic function of [N that] seems to be the same in the courtroom text (1) and in the linguistic paper (2). The aim of the speaker in using a head noun is to mark a personal stance towards a proposition; which is to say that the use of this grammatical pattern, as such, has no particularizing function in terms of text specificity.

However, the choice of nominal expressions may depend on the personal commitment of the speaker towards the proposition or on the way the proposition was expressed. Therefore, the speaker in (2) could characterize Ariel's position as Ariel's hypothesis, conclusion, or claim according to how she personally perceives it or upon the way Ariel expressed it. And in (1), the speaker in the courtroom, instead of using statement could use accusation, allegation or declaration depending on the way she perceives the proposition. It is also important to point out the difference in discursive strategies between the two examples. In (1), the testimonial source is not mentioned, whereas in (2) it is explicit, Ariel's.

These observations show that the choice of a head noun in a simple noun that-clause depends on the speaker's personal perception of the proposition she wants to characterize. We can then conclude that the use of this grammatical pattern in the discourse is motivated by the need to express one's own commitment towards a preconstruction. For instance, when the speaker says (the fact that ...), she wants to show the degree of her epistemic commitment about an observed event or state. And when she says (the order/requirement that), she obviously wants to show the deontic aspect of a preconstructed proposition or event. Indeed, that-clause as singularly a preconstruction is one of the differences between $[\mathrm{N}$ that $]$ and [There be $\mathrm{N}$ that $]$.

\section{Presentative that noun complement: [There be $N$ that-clause]}

(3) Judge Lumley Smith said there was no evidence that up to July 31 Hart had taken any part in the matter. He therefore ruled that there 
was no case to go to the jury as against Hart. Verdict (Hart), not guilty. (OBP)

(4) Labov (1978, p. 13), for example, claims that "there is ample evidence that human linguistic competence includes quantitative constraints as well as discrete ones." (JEL)

These two examples illustrate another type of lexico-grammatical pattern in which a noun governs a complement that-clause. Contrary to (1 and 2), the head noun in these utterances follows a 'presentativeexistential' structure, which constitutes the main clause. This formal difference between [ $\mathrm{N}$ that $]$ and [There be $\mathrm{N}$ that] is underpinned by a functional one. In both patterns, the main clause expresses the degree of the speaker's commitment. As in utterances ( 1 and 2$)$, the speaker in (3 and 4) characterizes and expresses her personal commitment (there was no evidence / there is ample evidence) towards the proposition. Nonetheless, there is a subtle difference between (1/2) and (3/4), since in the former, the assertion (main clause) is about the speaker's judgment on the propositional content; whereas in the latter, it is about the existence of the propositional content. This difference can be summed up as in the table 1:

\begin{tabular}{|c|c|c|}
\hline Clauses & [N that $]$ & [Presentative $\mathbf{N}$ that $]$ \\
\hline $\begin{array}{l}\text { Main clause } \\
\text { (Direct } \\
\text { assertion) }\end{array}$ & $\begin{array}{l}\text { Nominal characterization } \\
+ \text { personal judgment about } \\
\text { the propositional content. } \\
\text { Ex.: The statement (that ...) } \\
\text { is a lie in the legal sense }\end{array}$ & $\begin{array}{l}\text { Nominal characterization } \\
+ \text { assertion the existence of } \\
\text { the propositional content. } \\
\text { Ex.: There was no evidence } \\
\text { (that ...) }\end{array}$ \\
\hline That-clause & Propositional content & Propositional content \\
\hline
\end{tabular}

Table 1. - Semantic differences between [N that] and [There be $\mathrm{N}$ that].

We can notice that the distinction in grammatical patterns correlates with a semantic difference. In both [N that] and [Presentative $\mathrm{N}$ that] there is a nominal characterization of the propositional content. But contrary to the former, the speaker in using [There be $\mathrm{N}$ that] does not express a personal judgment about the proposition. In presentative that-clauses, the speaker asserts the proposition "as actually existing independently of the speaker" Perkins (1983, p. 67), i.e. the proposition is presented as "true for any speaker", and the speaker does not give any personal comment. Notice however that the testimonial source of 
the modal expression can be explicitly stated (there was evidence for the jury that ... OBP).

It is also worth noting that the speaker uses other devices to express the degree of her commitment about the propositional content. In (3 and 4), we can remark that in the main clauses the speaker uses devices such as negation (no evidence ...) or an adjective (ample evidence ...) to reinforce the degree of her commitment; a commitment whose modality type is determined by the head noun. In the utterances, the noun evidence conveys an epistemic characterization. And the type of modal expression could for example be deontic as in:

(5) On August 14 there was an Admiralty order that this man's name should be removed from the Navy List. (OBP)

In this utterance, the speaker reports on the existence of a proposition (that this man's name ...), which is deontic in nature (Admiralty order) and whose source is explicit. Thus, one can conclude that the source of modality can be mentioned in most that noun complement constructions; which is also the case in predicative that noun complement clauses, discussed below.

\section{Predicative that noun complement: [N - be that-clause]}

(6) Dr. FORWOOD, medical officer, Holloway Prison. I have had the prisoner under observation since December 7. My conclusion is that at the time of committing this act she was not responsible for her actions.

Verdict, Guilty, but insane at the time of commission of the offence. (OBP)

(7) The implication of these findings is that the process was diffused from above in the sense that it was promoted by professional usage. (JEL)

These utterances involve a nominal characterization of the propositional content. In both sentences, instead of a simple declarative utterance (6' and 7'), the speaker uses a sort of indirect assertion -"mode indirect" (Colletta, 1994, p. 89) in enveloping the propositional content in a nominal expression.

(6') At the time of committing this act she was not responsible for her actions.

(7') The process was diffused from above ... 
The nominal expressions (conclusion and implication), which constitute a kind of epistemic shell denote the speaker's commitment towards the propositional content, (Schmid, 2000). In (6), the degree of the speaker's commitment is conveyed by the term conclusion, the modal epistemic source of which is the speaker herself, My (Dr. Forwood). And in (7), the epistemic source is the findings; the speaker's commitment is measured by the epistemic noun implication. Thus, the propositional contents of (6 and 7) are both characterized by conclusion and implication respectively. To sum up, one can state that subject predicative that-construction is a process in which the speaker uses a noun as a modal shell to express a personal stance towards what she is asserting. In these constructions, there is an identification or description process between the head noun and the propositional content.

Note that although the head nouns in both utterances are epistemic, they do not have the same purpose or interpretation. In the courtroom situation, the choice of the epistemic expression has a precise purpose and effect on the verdict (guilty or not guilty); whereas in the academic writing context, the purpose and effect are to convince and have the adherence of the reader. So, these differences in purposes and effects may be crucial for the choice of the modal nominal. That is to say that the use of such or such modal nominal, as a stance marker, in such or such context may depend not only on the degree of the personal commitment towards the proposition, but first and foremost on the extralinguistic purposes of the utterance or of the overall writing-speaking context. For example a judge would probably use (There is no evidence that) instead of (My impression is that) when he/she delivers the verdict. Similarly a linguist would be reluctant to use impression in an utterance like (A first observation [...] is that the metalinguistic labels respondents volunteered were frequently the same. JEL) This is in line with Biber et al. (1999, p. 649) who point out that in an academic writing observation as a head noun (over 10 times per million words) is twice more frequent than impression (over 5 times per million words).

Furthermore, the use of the term conclusion by a medical expert in a courtroom is not at all the same as the use of the same term by a researcher in an academic paper. Pragmatically, it is even somehow obligatory (or at least customary) for the medical expert in a courtroom to use the term conclusion in an utterance like (6); whereas the linguist in (7) could use conclusion, inference, result, etc. As a matter of fact, conclusion is used three times in the legal corpus, and in all the uses 
by a medical expert. This means that the choice of a head noun in a given text is not necessarily oriented by its lexical semantic meaning, but rather by the targeted pragmatic function and effect.

\section{Discussion}

Data analysis has revealed that the overall use of that noun complement clauses is much more frequent in an academic research paper than in a courtroom discourse. So, this confirms Biber et al.'s (1999, p. 648) observation that "that-clauses functioning as noun complements are one of the primary devices used to mark stance in academic prose." The table below illustrates this contrast.

\begin{tabular}{|c|c|c|}
\hline $\begin{array}{l}\text { Noun complement } \\
\text { clauses }\end{array}$ & $\begin{array}{l}\text { Courtroom corpus } \\
44 \text { occurrences, } 28 \%\end{array}$ & $\begin{array}{l}\text { Linguistic corpus } 115 \\
\text { occurrences, } 72 \%\end{array}$ \\
\hline$[(\mathrm{V}) \mathrm{N}$ that $]$ & $3(7 \%)$ & $52(45 \%)$ \\
\hline $\begin{array}{l}\text { [Presentative-existential } \\
\mathrm{N} \text { that }]\end{array}$ & $\begin{array}{l}13(30 \%)(8 \text { There be } \\
\text { that / } 5 \text { It be } N \text { that })\end{array}$ & $\begin{array}{l}12(10.50 \%)(7 \text { There } \\
\text { be that / } 5 \text { It be N that })\end{array}$ \\
\hline [N be that $]$ & $14(32 \%)$ & $25(22 \%)$ \\
\hline [Support-V N that] & $9(20 \%)$ & $12(10.50 \%)$ \\
\hline$[\mathrm{PP} N$ that $]$. & $\begin{array}{l}5(11 \%) \text { (with intent } \\
\text { that) }\end{array}$ & $\begin{array}{l}10(8.50 \%) \text { (in the } \\
\text { sense that) }\end{array}$ \\
\hline [N be $\mathrm{N}$ that $]$ & - & $\begin{array}{l}4(3.50 \%) \text { (a particu- } \\
\text { larly valuable feature } \\
\text { of chapter } 3 \text { is the fact } \\
\text { that) }\end{array}$ \\
\hline
\end{tabular}

Table 2. - Types of that-noun complement clauses in the corpora.

One can observe in the table that the linguistic corpus contains nearly three times more complement that-clauses (72\%) than the courtroom corpus (28\%). This may be related to the fact that one is much more likely to comment on preconstructions (for instance previous works or ideas on the topic one discusses) in a research paper than in a courtroom. The researcher, in her analysis of facts, ideas, or findings would inevitably have to discuss, characterize and comment on other researchers' works and ideas. That is probably why she often must recourse to head nouns in order to carry out those necessary characterizations and assessments. Biber et al.'s (1999, pp. 648-9) illustration of the most common head nouns in academic prose supports this claim. 
In the sections below, we firstly discuss some observations to prove the claim that head nouns are used as modal stance marker. Then we analyze if head nouns as modal devices and the grammatical patterns in which they appear are used to achieve specific text purposes. And finally we tackle the issue of text institutional functions and particular lexical usage.

\section{II.1. Head nouns as modal stance markers}

The confrontation of our two corpora confirms that head nouns are actually used by the speaker to express a personal modal assessment and characterization of the propositional content. As modal expressions, the head nouns we found in the corpora belong to the following modal classes:

\begin{tabular}{|c|c|c|}
\hline Modal classes & Courtroom corpus & Linguistic corpus \\
\hline $\begin{array}{l}\text { Epistemic } \\
\text { nouns }\end{array}$ & $\begin{array}{l}\text { Allegation, Assumption, } \\
\text { Conclusion }{ }^{1} \\
\text { Doubt, Evidence, Fact, } \\
\text { Idea, Impression, } \\
\text { Knowledge, Note, Opinion, } \\
\text { postcard Practice, } \\
\text { Probability, Reason, } \\
\text { Result, Sign, Statement, } \\
\text { Suspicions, Support, View } \\
{[21]}\end{array}$ & $\begin{array}{l}\text { Argument, Assertion, } \\
\text { Assumption, Basis, Belief, Case, } \\
\text { Claim, Conclusion, } \\
\text { Counterclaim, Contention, } \\
\text { Doubt, Evidence, Feeling, Fact, } \\
\text { Generalization, Hypothesis, } \\
\text { Idea, Ideology, Implication, } \\
\text { Indication, Inference, } \\
\text { Interpretation, Intuition, Nature, } \\
\text { News, Notions, Observation, } \\
\text { Perception, Point, Possibility, } \\
\text { Questions, Reason, Sense, } \\
\text { Statement, Support, View [36] }\end{array}$ \\
\hline Deontic nouns & $\begin{array}{l}\text { Arrangement, } \\
\text { Condition, Intent, } \\
\text { Order, Regulations, } \\
\text { Rule, Word Of honour [7] }\end{array}$ & {$[0]$} \\
\hline $\begin{array}{l}\text { Attitudinal- } \\
\text { evaluative } \\
\text { nouns }\end{array}$ & {$[0]$} & $\begin{array}{l}\text { Advantage, Aspect, Concern, } \\
\text { Flaw, Guarantee Hope, Impact, } \\
\text { Innovation, Motivation, Part, } \\
\text { Problem, Value, Wisdom [13] }\end{array}$ \\
\hline Types: 77 & 28 & 49 \\
\hline Tokens: 159 & 44 & 115 \\
\hline
\end{tabular}

Table 3. - Modal classification of head nouns and their frequency.

7. Head nouns in bold are the ones that occur in both corpora. 
Epistemic nouns are used by the speaker to express "an assessment of the certainty of the proposition [... and] an indication of the source of the knowledge expressed in the that-clause." (Biber et al., 1999, p. 648.) Notice that 14 of the epistemic head nouns in our linguistic corpus are among the nouns that Biber et al. have identified as the "23 most common head nouns" in the academic genre (Biber et al., 1999, p. 648).

As for the deontic class, in addition to the semantic meaning of the head noun, the form of the verb in the that-clause highlights the deontic implication. All the deontic head nouns in the legal corpus are noticeably followed by either a putative should or by other modal auxiliaries like must, have to, would or shall. When we look at the occurrences, we can observe that the use of should or the other modal auxiliaries is triggered by the head noun. Examples ( 8 and 9 ) illustrate the deontic implication of the head nouns, but also that of the verb forms in the subordinate clauses.

(8) The rule with regard to drivers' licenses is that applicants must produce satisfactory evidence of good conduct and sobriety during the past three years. (OBP)

(9) I forwarded the report to the Commander-in-Chief and orders were given that an investigation should be held. (OBP)

In these utterances, one can notice that there is a strong deontic relationship between the head nouns (rule and orders) and the deontic auxiliaries (must and should).

Another type of head noun, which occurs exclusively in our linguistic corpus, is the 'attitudinal-evaluative' nouns. Similar to the other kinds of head nouns, attitudinal-evaluative nominals are also used by the speaker to characterize the propositional content. However, instead of characterizing the proposition in terms of commitment, these kinds of modal nouns are rather used by the speaker to express positive, negative or neutral assessments about a proposition, an event or a state. In the examples below, one can notice that the writer uses the head nouns (advantage, flaw, and part) to convey attitudinal-evaluative characterization, which are respectively positive, negative and neutral.

(10) The great advantage of this corpus is that it contains entire texts rather than extracts. (JEL)

(11) The obvious flaw in this otherwise attractive explanation is that there is nothing to suggest that Westerners outnumber speakers of other dialects in the migrant population. (JEL) 
(12) ... the historical part of the argument is that since Old English did not have articles, syntactic analyses that depend on them are inadequate. (JEL)

Notice that except hope and wisdom all the attitudinal-evaluative head nouns in the corpus are used in the predicative that-clause pattern. This may be explained by the identifying and interpretative functions of this grammatical pattern. The hypothesis is that attitudinal-evaluative expressions lend themselves more easily to the identifying and interpretative role of subject predicative rather than to the adjacent characterization of simple or presentative that-noun clauses.

\section{II.2. Nominal modal expressions and textual strategies}

Throughout the data analysis, we have noticed that the different grammatical patterns of noun that-clauses may not have the same communicative functions and effects according to text genres.

For instance the presentative that-clause has different pragmatic purposes and effects in linguistic and courtroom corpora. In the courtroom, when the judge says "there was no evidence that ...", on the one hand she aims at showing the degree of her commitment towards the propositional content. But on the other hand, the main purpose of this modal shell is to claim or announce the discharge of the defendant. Pragmatically, the utterance implies that the defendant is not guilty. Whereas on the contrary, in the academic writing context, when the speaker says "there is ample evidence that ..." she of course shows the degree of her commitment, but does not seek any extra-linguistic effect other than convincing the reader.

Likewise, in (I.3), we have shown that the extra-linguistic purpose of a modal expression in a predicative that-clause can depend on the contextual genre of the text. The remarkable absence of attitudinalevaluative expressions in the courtroom text may plead in favor of this claim. Speakers in a courtroom may willingly avoid using expressions that convey positive or negative judgments on what they or others say. The same hypothesis might explain the scarcity of [ $\mathrm{N}$ that $]$ constructions in the courtroom text (only 3 occurrences). Bearing in remind that the main particularity of this construction is that, in addition to the modal nominal characterization, the speaker expresses a personal judgment about the propositional content. 


\section{II.3. Lexical expressions and the institutional role of texts}

Based on corpus statistics, one can assume that the social role of a text may be perceived in the use and frequency of lexical items. In other words, the frequency of certain modal expressions seems to be related to the genre of text. Thus, if we take for granted the statistics, we can conclude that the authoritative role of the legal institution is noticeable in the lexical modal devices of its text. For instance, the legal text, which contains three times less that noun complement clauses (28\% versus $72 \%$ in the linguistic corpus) has seven times more deontic head nouns than the latter. In fact, the linguistic corpus does not contain any deontic nouns, whereas the legal one contains seven: (order, regulations, rule, word of honour, arrangement, condition, intent). Can we relate this to the authoritative role of the institution? And interestingly, the high frequency of epistemic nouns in the linguistic corpus (36 head nouns out of 49) may have something to do with its persuasive and nonauthoritative function.

\section{Conclusion}

In this study, we have shown on the one hand that nouns used to govern complement that-clauses involve modality, and lend themselves to a modal classification. Thus, via different that-clause patterns, the speaker can express a personal position on the propositional content [ $\mathrm{N}$ that $]$, point out the existence of a proposition [Presentative $\mathrm{N}$ that], or present the proposition as an identification of the head noun [ $\mathrm{N}$ be that]. Nevertheless, the essence of all of the three patterns is to modally characterize the propositional content.

On the other hand, we have tried to understand how text genres and purposes are construed through head nouns. The analysis has firstly revealed that head noun types and frequency are proportional to text genres. Secondly, it has shown that same heads nouns or that-clauses may not have the same discursive functions or effect in two genres of text; which is to say that that-clauses have different pragmatic interpretations with respect to text purposes or social role.

Finally, we have to add that large contrastive studies should be carried out to see to what extent the use of modal expressions in general and nominal ones in particular is correlated to text genres. Such studies would provide keys to understanding text specificity and purposes in relation to modality. 


\section{BIBLIOGRAPHICAL REFERENCES}

Aktas R.N. and Cortes V. (2008): "Shell nouns as cohesive devices in published and ESL student writing", Journal of English for Academic Purposes, vol. 7, pp. 3-14.

BALLIER N. (2007): "La complétive du nom dans le discours des linguistes", In D. Banks, La coordination et la subordination dans le texte de spécialité, Paris, L'Harmattan, pp. 55-76.

BALLIER N. (2004a): "Deverbal nouns as heads of noun complement clauses in English", communication au Colloque international sur les noms déverbaux, Université Lille 3, France, 23-25 septembre 2004, In Dossier en vue de l'Habilitation à diriger des recherches, Université Paris 10, document non publié, vol. II, Travaux, pp. 4-35.

BALLIER N. (2004b): "La grammaticalisation des contenus discursifs dans les complétives nominales", In Praxis métalinguistiques et ontologie des catégories, Synthèse des travaux de recherche en vue de l'Habilitation à diriger des recherches, Université Paris 10, document non publié, vol. I, Synthèse, pp. 43-54.

Biber D., Johansson S., Leech G., Conrad S., and Finegan E. (1999): Longman Grammar of Spoken and Written English, Essex, Longman.

ChEVALIER G. and LÉARD J.-M. (1996): "La subordination nominale : classes, sous-classes et types sémantiques", Linguistische Arbeiten, no. 351, pp. 53-65.

Colletta J.-M. (1994): "Identité et légitimité discursives dans les interactions au tribunal", Sciences pour la communication, vol. 41, pp. 87-99.

Huddleston R. and Pullum G.K. (2002): The Cambridge Grammar of the English Language, Cambridge, Cambridge University Press.

Nomura M. (1993): "The Semantics of the Content Clause Construction in English", English Linguistics, vol. 10, pp. 184-210.

Perkins M.R. (1983): Modal Expressions in English, London, Frances Pinter Publishers.

Quirk R., Greenbaum S., Leech G., and Svartvik J. (1985): A Comprehensive Grammar of the English Language, London/New York, Longman.

Schмid H. (2000): English abstract nouns as conceptual shells: From corpus to cognition, Berlin, Walter de Gruyter. 